\title{
Interrogation of prisoners after 2003: the role of health professionals
}

\author{
Jeremy Hugh Baron
}

J R Soc Med 2007; 100:265-266

Human rights abuses of prisoners in Afghanistan, Guantánamo Bay and Iraq have been extensively documented. ${ }^{1,2}$ I discuss only the role of health workers in the interrogation of prisoners at these sites.

In his August 2004 article for the Lancet, Steven Miles cited American governmental memoranda permitting during interrogation 'dietary manipulation (monitored by med)', dogs, drugs, isolation and nudity. ${ }^{3}$ The Genevabased International Committee of the Red Cross, founded in 1863, reported in November 2004 that in Guantánamo Bay, doctors and other health personnel aided interrogators with information about prisoners' mental health and vulnerability, either directly or through 'Biscuit'-BSCT, the Behavioral Science Consultation Team of psychologists. ${ }^{4}$ This three-member behavioural-science service consisted of Dr K, a military psychiatrist and internist, and two psychologists, Dr D and Dr H-the latter had undergone Survival, Evasion, Resistance and Escape (SERE) training. ${ }^{5}$

\section{HUNGER STRIKE}

Detainees on hunger strike have been restrained and forcefed, contrary to the World Medical Association Declarations of Tokyo and Malta, to which the American Medical Association was a signatory. ${ }^{6,7}$ However, Captain E, an emergency physician and commander of the medical group, stated 'the involuntary feeding was authorized through a lawful order of a proper military authority' and civilian doctors in US federal prisons are permitted to order the force-feeding of hunger strikers. ${ }^{5}$ Captain E was awarded a medal for 'his inspired leadership and exemplary performance'; his policies are being continued by his successor. ${ }^{6}$ Indeed, health-care staff at Guantánamo Bay are screened to ensure their agreement to forcefeed. ${ }^{6}$

\section{ABUSES AT INTERROGATION}

At least three interrogators made formal complaints to their commander; they were threatened and disciplined. ${ }^{8}$ Detainees had to be 'medically and operationally evaluated as suitable' for interrogation. A physician and a psychiatrist helped to design, approve and monitor interrogations at

Imperial College Faculty of Medicine, London

Email: hughbaron@aol.com
Abu Ghraib, Iraq. The medical staff revived a detainee who collapsed unconscious; they then left and the abuse continued. Death certificates were falsified or delayed for months. There is little evidence that medical staff refused or reported such abuses. ${ }^{7}$

\section{PROTECTION OF PRISONERS BY HEALTH CARE WORKERS IN THE 18th AND 21 st CENTURIES}

In 1773 two Viennese state doctors fulfilled their responsibilities to protect prisoners at interrogation by refusing to certify the continued torture of two prisoners, and also persuaded the Faculty of Medicine to campaign against torture. ${ }^{9}$ A liberal journalist jurist campaigned publicly, as well as privately, to the Empress Maria Theresa and to the Emperor Joseph II. The Empress abolished all forms of torture in 1776, and after her death the Emperor abolished serfdom in 1781 and the death penalty in 1787 .

In 2005, in the US, the relevant professional societies gave different specific instructions to their members. The American Psychological Association allowed '. . . psychologists to serve in consultative roles to interrogation and informationgathering processes for national security related purposes. ${ }^{\text {, }, 7}$ The American Psychiatric Association stated that psychiatrists should not participate or serve as consultants for the coercive interrogation of prisoners. ${ }^{5,10}$ The American Medical Association asked the US Defence Secretary whether doctors were complicit in the torture of prisoners. ${ }^{11}$

The American Army Surgeon General claimed that of the 1200 medical personnel serving in Afghanistan, Guantánamo Bay and Iraq, only 5\% said that prisoners had reported having been abused, and not one of the clinicians he surveyed had reported seeing actual or suspected abuse of any prisoner in Afghanistan. ${ }^{12}$ Miles could name only two who protested, and he asked, 'What led Dr Michael Gelles, the chief psychologist of the Naval Criminal Investigative Service, to carry his protest to the highest levels of the Pentagon? Sergeant Joseph Darby cited his Christian faith as the reason for slipping a disk with the Abu Ghraib photographs under the door to investigators.' ${ }^{13}$ Similarly, the final factor in the refusal of a military commissioner, Colonel Couch, to prosecute a prisoner who 
had been tortured was a sermon when the priest asked his congregants to 'respect the dignity of every human being.' 14

\section{CONCLUSION}

All whistle-blowers need courage to expose the misdeeds of their superiors and colleagues. Whistle-blowing armed services health workers need extraordinary courage to betray built in 'don't rock the boat' esprit de corps, and, without full support from their national professional bodies, challenge institutional rejection of international law.

Competing interests None declared.

Funding None.

Guarantor JHB.

\section{REFERENCES}

1 Greenberg KJ, Dratel JL, eds. The Torture Papers: The Road to Abu Ghraib. New York: Cambridge University Press, 2005

2 Miles SH. Oath Betrayed: Torture, Medical Complicity, and the War on Terror. New York: Random House, 2006
3 Miles SH. Abu Ghraib: its legacy for military medicine. Lancet 2004;364:725-9

4 Lewis NH. Red Cross finds detainee abuse in Guantánamo. New York Times 30 Nov 2004;A1:A19

5 Okie S. Glimpses of Guantánamo-medical ethics and the war on terror. N Engl J Med 2006;353:2529-34

6 Nicholl DJ, Atkinson HG, Kalk J, et al. Forcefeeding and restraint of Guantánamo Bay hunger strikers. Lancet 2006;367:811

7 Lifton RJ. Doctors and torture. N Engl J Med 2004;351:415-6

8 Miles SH. Oath Betrayed: Torture, Medical Complicity, and the War on Terror. New York: Random House, 2006:137

9 Baron JH. Folter Arzt: interrogation of prisoners in Austria in 1773. J R Soc Med 2007; 100:262-4

10 Ahuja A. The Guantánamo suicides reopen a festering question of medical ethics. The Times (London) 26 June 2006:19

11 Mayor S. AMA calls for inquiry into doctors' role in abuse of prisoners. BMJ 2006;329:993

12 Miles SH. Oath Betrayed: Torture, Medical Complicity, and the War on Terror. New York: Random House, 2006:134

13 Miles SH. Oath Betrayed: Torture, Medical Complicity, and the War on Terror. New York: Random House, 2006:166

14 Bravin J. The conscience of a US colonel: Lt Col V Stuart Couch prosecuted terrorists, until he decided a prisoner had been tortured. Wall Street Journal 4 April 2007:16-17 